\title{
Regional climate and energy strategies: actors, responsibilities, and roles
}

\author{
J. Palm \\ Department of Thematic Studies - Technology and Social Change, \\ Linköping University, Linköping, Sweden. \\ Tel: +46 13285615, Fax: +46 13284461, E-mail: jenny.palm@liu.se
}

\begin{abstract}
Since 2008, the Swedish regional authorities, i.e., the County Administrative Boards (CABs), have been exhorted to produce regional climate and energy strategies indicating how sustainable energy systems might develop in the future. I analyze the CAB role and mandate to coordinate and promote the development of regional climate and energy strategies. How do other regional and local actors perceive the CAB role, mandate, and legitimacy in relation to work on regional climate and energy strategies? Case studies were conducted in two counties where $\mathrm{CAB}$ representatives, municipal politicians, municipal climate and energy consultants, and Regional Energy Agency and Regional Cooperation Council representatives were interviewed in-depth.
\end{abstract}

The results of the interviews indicate that it was difficult for interviewed actors to explain how the tasks and responsibilities differed between the CAB, Regional Energy Agency, and Regional Cooperation Council; the representatives of these three bodies also experienced this difficulty. The CAB's leading role in the energy strategy work was accepted by the other stakeholders, but only because the other regional actors currently lacked the resources to take on such work. In the future, the Regional Cooperation Councils will be the main legitimate $\mathrm{CAB}$ competitors, willing to take over the strategic energy work.

Keywords: regional planning; strategy; accountability; legitimacy, network; planning theory, governance

\section{Introduction}

In Sweden, the regional administrative level has generally been weak while the municipalities have been in a strong position. However, since 2008 the Swedish regional authorities, i.e., the County Administrative Boards (CAB), have been exhorted to produce regional climate and energy strategies indicating how sustainable energy systems might develop in the future. In this paper, I will discuss these strategic plans in relation to questions concerning their legitimacy and accountability.

The central government wants to strengthen the role of CABs in developing sustainable energy systems, and accordingly chose to assign them coordination responsibility [1]. The $\mathrm{CAB}$ role and tasks were debated by the Committee on Public Sector Responsibilities (Ansvarskommittén). From 2003 to 2008, this Committee was commissioned to analyze the current system of public administration and to determine whether changes were required in the division of responsibilities and in structural arrangements in order to meet the challenges public sector services will face in the future [2]. To remedy these structural deficiencies, the Committee proposed a new regional system of public administration with clearer roles and a clearer division of responsibilities, and regionalization that is the same for the state and the local government sector. As regards regional development, development tasks characterized by self-governance were distinguished from tasks that were more purely a matter of carrying out government agency mandates. Consequently, it was proposed that County Councils be replaced by directly elected regional authorities with overall responsibility for regional development and health and medical care.

The Committee on Public Sector Responsibilities wanted this regional development mandate to be assigned to the newly established regional authorities. At the same time, the CAB tasks and mandate would be concentrated, focusing on central government coordination, 
supervision, permits and other legal applications, follow-up, evaluation, and cross-sectoral knowledge creation. The Committee's proposals were, however, not realized. As we will see, their investigation has had consequences for how local and regional actors reason about their responsibility and legitimacy in relation to developing regional energy and climate strategies.

In this context, I will analyze the CAB role and mandate to coordinate and promote the development of regional climate and energy strategies. How do other regional and local actors perceive the $\mathrm{CAB}$ role, mandate, and legitimacy in relation to work on regional climate and energy strategies? Over the past decade, several public actors in the regional arena have wanted to take responsibility for regional energy issues. These include the Regional Cooperation Council, organized by the municipalities in a county, which wants to assume overall responsibility for regional development. In addition, more regions have acquired a Regional Energy Agency with a regional focus on energy issues. Then we have local officials and politicians who want to keep their power of self-government on these issues. This paper will examine four actors: municipal politicians, municipal climate and energy consultants, Regional Energy Agencies, and Regional Cooperation Councils. I am interested in how these actors perceive the division of issues and responsibilities between actors at the regional administrative level in the energy system.

\subsection{Methodology and material}

Two case studies were conducted in two counties, Dalarna and Östergötland, where I interviewed regional and local actors concerned with the CABs' ongoing work on regional climate and energy strategy.

I interviewed one CAB representative in Östergötland and two in Dalarna. The CABs are state-controlled regional authorities that, among other tasks, are commissioned by the central government to develop regional climate and energy strategies.

In Dalarna, I also interviewed one representative of the Regional Energy Agency (REA). REAs are financed by the Swedish Energy Agency, EU, CABs, and Regional Cooperation Councils. They are commissioned to promote energy efficiency and the use of renewable energy sources.

The Regional Cooperation Councils (RCCs), mentioned above, handle regional cooperation between the municipalities in a county and the County Council (landstinget). RCCs are a politically controlled municipal interest organization commissioned to support the municipalities and facilitate cooperation and coordination between them. I interviewed one RCC representative from Östergötland and one from Dalarna.

I also interviewed nine municipal climate and energy consultants from Östergötland and five from Dalarna. They provide municipal energy guidance, disseminating objective knowledge of environmentally friendly energy sources, energy distribution, and energy use. We also interviewed six municipal politicians from Östergötland and five from Dalarna. Altogether, 31 interviews were conducted.

Interviews were used to gain an understanding of actor perceptions of the process and outcomes of developing regional energy strategies. I am interested in the background stories of and in-depth information on participants' experiences of this process. In the analysis, I compare the actors' descriptions of the process and search for patterns. While quantitative data concern differences in degree of aspects of a studied entity, qualitative data concern 
similarities or dissimilarities between studied entities. Interview analysis is descriptive, and aims to go beyond merely describing the responses to the interview questions. The analysis entails the researcher, through reflection, abstracting from the descriptions and seeking patterns and dysfunctions in light of earlier studies or theories [3]. Taking the particular conclusions relating to Östergötland and Dalarna and generalizing them to other regions is not of interest; what is of general interest is analysing the actors' roles, responsibilities, legitimacy, and inclusion in and exclusion from the process. In other words, analytical generalization is of interest here, not statistical generalization [3].

\section{Regional strategic planning: legitimacy and responsibility}

Swedish CABs have been commissioned to develop regional climate and energy strategies. The meaning of strategic planning is an empirical question, and depends on what efforts particular actors put into it. Healey [4] emphasizes that strategic work aims to change the direction of an activity (in this case, a technical system), open up new possibilities and potentials, and move away from previous positions. These strategies are social products embedded in the governance cultures of particular regions [4,5]. A regional strategy functions by articulating an orientation shared by many stakeholders in a regional development process. Because strategies are social products formed in networks within governance structures, questions concerning legitimacy and accountability are vital for working strategies that influence the direction of regional energy systems.

According to $\mathrm{CAB}$ budget documents, regional sustainable energy systems are to be developed by creating arenas and processes where regional actors can meet and develop common strategies and goals. Such processes are often collectively labelled governance. Theories of governance often draw attention to how and why actors that are not part of the political sphere participate in forming politics in the broad sense, and to how new arenas and coordination forms are created and used [6,7].

Democratic legitimacy concerns how the governed are interested in and understand political legitimacy. A policy is seen as legitimate by concerned actors if there is principal consent, i.e., if concerned parties think the policy is legitimate and if they agree on norms and values. Legitimacy can also be conferred by active consent, referring to acts indicating approval, such as actor participation in projects, reference groups, etc., initiated by the actors seeking legitimacy [8].

In a government context, accountability is generally regarded as a chain extending from the electorate to the elected politicians and from the politicians to the public administration. The new localism and complexity of governance structures make accountability intertwined and multiple [9], imbuing it with new meanings. The role of government then changes: it becomes just one player among many [10]. Governance structures have developed in response to the state's increased need to mobilize actors, and their resources, outside their formal contexts to formulate and implement public policy [11].

Mitchell and Shortell [12] argue that accountability is "defined as a process by which a party justifies its actions and policies and is a key aspect of governance". The increasing complexity of governance through partnership permits a broader understanding of accountability, including bureaucratic/hierarchical, legal, professional, political, and moral/ethical dimensions [13]. 
In developing sustainable energy systems, CABs have been commissioned to establish strategic planning initiatives at the regional level. In practice, this means that they are responsible for promoting the issue; they should not do everything on their own, but work in cooperation with other actors. I will next discuss how this is done in practice.

\section{Dalarna and Östergötland counties work on regional climate and energy strategies}

Dalarna is often portrayed as a pioneer in regional energy work. Even before the government's 2008 budget document, it had worked to coordinate regional actors to deal with various energy issues. A regional energy programme had been developed from 2004 to 2005, “Energy Intelligent Dalarna - programme for regional energy coordination”, $1_{\text {in }}$ which representatives of municipalities, industries, and organizations in the region participated. Dalarna's first climate and energy strategy was completed in October 2008. The strategy is supposed to integrate visions and goals from Energy Intelligent Dalarna and provide a common overview of the entire region [14].

Östergötland's climate and energy strategy was developed in 2008, also in consultation with external stakeholders. In Östergötland, a special advisory group was formed, including the CAB, RCC, and the County Council, which met several times [15].

\subsection{Actor perceptions of roles, tasks, and responsibilities}

The representatives of the CABs of both Östergötland and Dalarna said that they were happy that the CABs had been responsible for working on the climate and energy strategies, saying that the work was in line with the CABs' long-standing commitment to environmental issues. The Östergötland representative offered one reason why the CABs had been assigned this task:

The CABs are the outstretched arm of the state in the regions, so that it is not so surprising, really. And the CABs have a coordination function in other contexts, too, and also in this cross-sectoral work.

Another option would be to allow the RCCs to coordinate regional energy planning. One representative of the Dalarna $\mathrm{CAB}$, however, said that it could be difficult for the government to give an assignment to an RCC, which is funded by and works on behalf of the county's municipalities. If the state wanted to commission the RCCs to develop regional planning, it would also need to fund the assignment; that was not necessary when the assignment went to the CABs.

It can generally be concluded that the vast majority of interviewees were aware that their $\mathrm{CAB}$ had worked on a climate and energy strategy. However, the actors had difficulties specifying what the CAB had worked on more exactly or the objectives associated with the strategy. The answers were more general, the CAB's work being described thus: "they should take a holistic approach", "review the region's energy balance", and "work on sustainable development”. The Dalarna CAB's work was slightly better known by the regional actors than was the Östergötland CAB's work. The regional actors in Dalarna could more easily cite concrete examples of the content and aims of the Dalarna energy strategy. The participants best remembered matters on which they had worked specifically with the $\mathrm{CAB}$, for example,

\footnotetext{
${ }^{1}$ Energilntelligent Dalarna - program för regional energisamverkan
} 
when the CAB had developed a template text for municipal energy plan, or held a seminar on a specific issue.

A common opinion among the municipal politicians was that the climate and energy strategy would convey the state's views on energy issues. Several also emphasized that the CAB was a state rather than a regional actor, and that it acted mainly as a supervisory authority.

\subsection{Division of tasks between regional actors}

The Östergötland CAB representative said that issues concerning both responsibility and implementation in relation to the strategy's goals and vision were not easy to sort out:

This is not easy - if one looks at the control, control over the actions, since there are many who must do things.

The CAB representatives from both Östergötland and Dalarna stressed the importance of cooperation and that a diversity of actors, for example, the business community and the university, needed to be coordinated. The Dalarna CAB established a legitimation process in which actors could participate by creating a steering committee that included the county governor, RCC president, and key sector representatives. This committee was a way to create legitimacy and commitment by involving regional actors.

The division of responsibilities between the various regional actors, such as the CABs, RCCs, and REAs, was not very clear to any of the interviewees. One of the municipal climate and energy consultants commented on the difference between the CAB and the REA's GDE-Net:

No, I don't know. They're the same ... I cannot see any distinct difference. (Climate and energy consultant Dalarna, 5)

In addition, a more integrated strategy was asked for at the regional level:

There are so many players now who work in the same direction. First, there's now the County Administrative Boards in general. Then we have the Environmental Protection Agency, with climate coaching, and then comes the Energy Agency with their ‘sustainable municipality’ programme. Actually, I think there are too many players. There should probably be just one regional player. (Climate and energy consultant Dalarna, 1)

\subsection{The difference between the CAB and the RCC}

The two regional players that were the biggest competitors in formulating and developing regional climate and energy strategies were the $\mathrm{CAB}$ and the RCC. According to the representative of Dalarna's RCC, the difference between the RCC and the CAB was that the CAB was a "clearly defined authority"; the RCC, on the other hand, "takes responsibility for regional development" in general, which is similar to the arguments of the Committee of Public Sector Responsibilities.

The representative of Östergötland's RCC Östsam said that the difference between the CAB and the RCC was unclear, but that they dealt with this periodically by recurring negotiations: 
It is never clear who is doing what, but the point is that you need to talk to each other and inform each other of what you are doing at the moment. And sometimes we can engage them in our activities and vice versa. But it isn't anything cast in stone, where you can say that this is the CAB's task and that is Östsam's. It may evolve over time, but now it's more that people talk to one another.

The municipal politicians discussed the problem of having two regional players, both driving the energy issue:

Yes, I'm one of those who may feel that, as it is today, it has become a little bit like parallel actors, with both Östsam and the County Administrative Board. And it has become a kind of dual control, which I find a bit unnecessary. (Municipal politician Östergötland, 1)

The politicians would like to see the roles streamlined, and said that the CAB's role should be to monitor issues, and that a different kind of regional player should be responsible for regional development.

The RCC representatives from both Dalarna and Östergötland wanted to run the climate and energy strategy in the future, as this was seen as an important development issue for the Council. Even the elected municipal politicians advocated an increased role for the RCCs. In Östergötland, all the politicians wanted the CABs to be mainly regulatory in function in the future, and wanted Östsam to be solely responsible for regional development. The same was true in Dalarna, but here the politicians wanted to see a clearer distinction between supervision and development in the long run.

Dalarna's RCC representative felt that energy was an important development issue for which they should be responsible; that, however, would require that the Council receive additional resources. In the current situation, the RCC lacked sufficient resources, and until the financial situation was resolved, the representative thought it was positive that the CAB was responsible for developing a regional energy strategy.

Östsam would like to see a trend towards greater responsibility being transferred to the RCC, and would like to see this transfer start immediately.

\section{Conclusions}

By means of a government directive in the 2008 budget document, the state indicated that regional energy strategic planning was important. The CAB's mission was made clear, and the CABs in Dalarna and Östergötland have taken initiatives to develop common goals, visions, and strategies in the regions.

In the current situation, the CAB has no real "competitor" in either Dalarna or Östergötland. In the future, it is primarily the RCCs that might compete with the CABs and would like to assume responsibility for energy strategy work. Both the RCCs and leading local politicians identified the RCC as the party that should handle this strategic work. This is because local politicians and RCCs would like to see development handled in line with the recommendations of the Committee on Public Sector Responsibilities, according to which 
CAB activities are limited to control issues and the RCCs would be responsible for regional development. This division of responsibilities can only be realized in the future due to the current lack of resources for RCCs. This lack also means that local politicians will continue to accept the CABs' current work and role until viable alternatives are available.

The roles of these actors, including the REA, are unclear. It was difficult for the interviewed actors to clarify their tasks and responsibilities. The representatives of the RCCs and CABs said that they divided tasks and responsibilities through ongoing dialogue with each other. When a question entered the agenda, they simply contacted each other to see how the issue could best be handled and by whom. This pragmatic system, however, is not very transparent to the actors excluded from the informal dialogue. With such an informal system, it is unclear how decisions are made and for what reasons, or who is accountable for a given decision. In addition, issues can fall through the cracks when no one is explicitly responsible for them.

Other issues raised are what will happen when the climate and energy strategies are to be acted on and the goals implemented. What legitimacy does a CAB strategy have in a county? Will it be just another document, among others, that the municipalities must take into account, and that will disappear among all the other documents? Assuming that a strategy reaches out to stakeholders, the problem of putting the goals and measures into practice remains. Another obstacle is that a CAB strategy may lack legitimacy and only be accepted because of lack of alternatives. The municipalities would like to see other agencies develop and implement regional goals and visions; it is too early to say what significance this might have for implementation, but it is an obvious hindrance and threat to united action in a region.

Local politicians are involved in the RCCs, which gives the Councils legitimacy and direct access to the municipal decision-making processes. In a situation of competition regarding future policies, CAB strategies will probably not attract support, because CABs are perceived as representatives of the central government rather than the regions. The RCCs, on the other hand, are working to create regional identities from below and represent local interests and not the state, which will benefit them in any future competition.

\section{Acknowledgements}

The research for this paper forms part of the research programme, Energy Choices in Households: A Platform for Change. This research was funded by the Swedish Energy Agency.

\section{References}

[1] Governmental Bill 2008/09:1, Budgetpropositionen.

[2] SOU 2007:13 (Swedish Government Official Reports), Regional utveckling och regional samhällsorganisation.

[3] R.K. Yin, Case Study Research: Design and Methods, Studentlitteratur, 1994.

[4] P. Healey, In search of the "strategic" in spatial strategy making, Planning Theory \& Practice 10, 2009, pp. 439-457.

[5] L. Albrechts, Strategic (spatial) planning reexamined, Environment and Planning B: Planning and Design 31, 2004, pp. 743-758.

[6] J. Pierre, Debating Governance: Authority, steering and democracy, OUP, 2000. 
[7] P.A. Sabatier \& H. Jenkins-Smith, Policy Change and Learning: An Advocacy Coalition Approach, Westview Press, 1993.

[8] J. Johannsson, Regionförsök och demokrati: Demokratisk legitimitet och regionalt utvecklingsarbete i Skåne och Västra Götaland, Forskning i Halmstad no. 10, Högskolan i Halmstad, 2005.

[9] G. Stoker, 2004, New localism, progressive politics and democracy, The Political Quarterly 75, pp. 117-129.

[10]J. Pierre \& G. Peters, Governance, Politics and the State, Macmillan, 2000.

[11]M. Considine, Making Public Policy, Polity Press, 2005.

[12]S. Mitchell \& S. Shortell, The governance and management of effective community health partnerships: A typology for research, policy and practice, The Milbank Quarterly 78, 2000, pp. 241-289.

[13]L. Dicke \& S. Ott, Public agency accountability in human services contracting, Public Productivity \& Management Review 22, 1999, pp. 502-516.

[14]Länsstyrelsen Dalarna, Klimat- och energistrategi för Dalarna, version 1, October 2008.

[15]Länsstyrelsen Östergötland (2008), Ett vinnande klimat: Klimat- och energistrategi för Östergötland. 